\title{
European freshwater VHSV genotype Ia isolates divide into two distinct subpopulations
}

\author{
S. Kahns ${ }^{1,5, *}$, H. F. Skall ${ }^{1}$, R. S. Kaas ${ }^{2}$, H. Korsholm ${ }^{3}$, B. Bang Jensen ${ }^{1,6}$, \\ S. P. Jonstrup ${ }^{1}$, M. J. Dodge ${ }^{4}$, K. Einer-Jensen ${ }^{1}$, D. Stone ${ }^{4}$, N. J. Olesen ${ }^{1}$ \\ ${ }^{1}$ National Veterinary Institute, Technical University of Denmark, 8200 Aarhus N, Denmark \\ ${ }^{2}$ National Food Institute, Technical University of Denmark, 2800 Kgs. Lyngby, Denmark \\ ${ }^{3}$ Section for Aquaculture, Danish Veterinary and Food Administration, 7100 Vejle, Denmark \\ ${ }^{4}$ CEFAS Weymouth Laboratory, Weymouth, Dorset DT4 8UB, UK \\ ${ }^{5}$ Present address: Danish Technological Institute, 8000 Aarhus C, Denmark \\ ${ }^{6}$ Present address: Norwegian Veterinary Institute, 0106 Oslo, Norway
}

\begin{abstract}
Viral haemorrhagic septicaemia (VHS), caused by the novirhabdovirus VHSV, often leads to significant economic losses to European rainbow trout production. The virus isolates are divided into 4 distinct genotypes with additional subgroups including sublineage Ia, isolates of which are the main source of outbreaks in European rainbow trout farming. A significant portion of Danish rainbow trout farms have been considered endemically infected with VHSV since the first disease outbreak was observed in the 1950s. However, following a series of sanitary programs starting in 1965, VHSV has not been detected in Denmark since January 2009. Full-length Ggenes of all Danish VHSV isolates that were submitted for diagnostic analyses in the period 2004-2009 were sequenced and analysed. All 58 Danish isolates from rainbow trout grouped with sublineage Ia isolates. Furthermore, VHSV isolates from infected Danish freshwater catchments appear to have evolved into a distinct clade within sublineage Ia, herein designated clade Ia-1, whereas trout isolates originating from other continental European countries cluster in another distinct clade, designated clade Ia-2. In addition, phylogenetic analyses indicate that VHSV Ia-1 strains have caused a few outbreaks in Germany and the UK. It is likely that viruses have been transmitted from infected site(s) out of the Danish environment, although a direct transmission pathway has not been identified. Furthermore, VHSV Ia-2 isolates seem to have been transmitted to Denmark at least once. Interestingly, one viral isolate possibly persisted in a Danish watershed for nearly 4 yr without detection whereas other subclades of VHSV isolates appear to have been eliminated, probably because of implemented eradication procedures.
\end{abstract}

KEY WORDS: Viral haemorrhagic septicaemia - Geographic subgroups - Molecular tracing • Genotype Ia-1 · Genotype Ia-2 · Epidemiology

\section{INTRODUCTION}

Viral haemorrhagic septicaemia (VHS) is a disease that affects many species of both marine and freshwater fish (Skall et al. 2005, OIE 2009). In Europe, the main species clinically affected by the disease is rainbow trout Oncorhyncus mykiss. Clinical signs are skin darkening, anaemia, exophthalmia and haemorrhages. The mortality can be as high as $100 \%$ in fry, leading to significant economic losses for the rainbow trout farming industry (OIE 2009).

The causative agent, VHS virus (VHSV), is a member of the genus Novirhabdovirus in the family Rhabdoviridae (Walker et al. 2000). The virion is en- 
veloped and contains a single-stranded negativesense RNA genome. The whole genome is approximately 11200 nucleotides in length and contains 6 genes, encoding a non-structural protein $(\mathrm{Nv})$ as well as the 5 structural proteins nucleocapsid- $(\mathrm{N}-)$, phospho- (P-), matrix- (M-), glyco- (G-) and RNA polymerase (L-) protein (Schütze et al. 1999).

Four main genotypes of VHSV have been identified based on N-gene and G-gene sequences (Snow et al. 1999, 2004, Einer-Jensen et al. 2004, Nishizawa et al. 2006, Elsayed et al. 2006). The genotypes seem to be more associated with geographical distribution rather than host species. Genotype II isolates are restricted to the Baltic Sea and rivers flowing into the Baltic Sea (Skall et al. 2005, Gadd et al. 2010). Genotype III isolates have been restricted to waters connected to the North Atlantic Ocean (Skall et al. 2005, López-Vázquez et al. 2006, Dale et al. 2009). In contrast, freshwater and marine isolates are present in both genotype I and genotype IV. Furthermore, both genotype I and IV are divided into sublineages. Based on phylogenetic analyses using full-length Ggene sequences, 5 sublineages of genotype I have been identified (Einer-Jensen et al. 2004). Almost all VHSV isolates causing outbreaks in European rainbow trout farms cluster in sublineage Ia, of which isolates have been reported from most continental European countries (Einer-Jensen et al. 2004, Snow et al. 2004, Toplak et al. 2010). However, genotype Ia isolates have also been detected in species such as brown trout, pike and grayling (www.fishpathogens.eu; Meier et al. 1994, Jonstrup et al. 2009). Most genotype Ia isolates have caused outbreaks in freshwater farms, but isolates have also been obtained from rainbow trout in seawater netpens and in at least one case from turbot (Schlotfeldt et al. 1991, Snow et al. 2004). Genotype Ib viruses have only been isolated from fish in the marine environment in the Baltic Sea, Kattegat, Skagerrak, the North Sea and the English Channel (Einer-Jensen et al. 2004, Snow et al. 2004). Genotype Ic is a smaller group consisting of Danish rainbow trout isolates from earlier dates. VHS outbreaks in Finnish seareared rainbow trout in the Baltic Sea grouped together in genotype Id (Raja-Halli et al. 2006), together with some old Scandinavian isolates from the 1960s. Genotype Ie isolates have been obtained from both the freshwater and the marine environment in Georgia and Turkey (Nishizawa et al. 2006). Genotype IV isolates, from North America and Asia (Skall et al. 2005), are divided into the sublineages IVa and IVb, of which IVa is primarily restricted to the marine environment in both North America and
Asia (Meyers \& Winton 1995, Nishizawa et al. 2002, Kim et al. 2003, Hedrick et al. 2003, Lee et al. 2007), whereas sublineage IVb isolates have been observed in both freshwater and marine systems in North America only (Gagné et al. 2007, Kane-Sutton et al. 2010, Thompson et al. 2011).

The initial cases of VHS were reported from the Danish rainbow trout farming industry in the 1950s (Schäperclaus 1954, Rasmussen 1965), and in 1965, as many as $\sim 400$ farms out of a total of approximately 750 farms were considered infected (Fig. 1) (Olesen \& Korsholm 1997, Olesen 1998). Since then, several sanitation programs have been implemented, which has reduced the number of infected farms dramatically. In 1965, a private control program was initiated on a voluntary basis followed by an official program in 1970. These programs reduced the number of infected farms from 400 in 1965 to 5 in January 2009 (Fig. 1). A final eradication program, preceded by fallowing of the remaining infected farms, and approved by the European Union (EU) (EU Commission 2008), was initiated on 1 April 2009. No VHS outbreaks have occurred in Denmark since January 2009. If the eradication plan is successful, Danish freshwater aquaculture can be declared officially free of VHS according to EU legislation (EU Council 2006) by 1 April 2013.

Because of the single-stranded RNA genome of VHSV, the virus displays an error-prone replication mechanism that contributes to the rapid evolution and large sequence diversity within RNA viruses (Holmes 2009) and facilitates studies in genetic diversity and transmission pathways. The present study shows that genotype Ia isolates can be divided into 2 clades: Danish isolates have evolved into a distinct clade that we designate clade Ia-1, whereas clade Ia-2 VHSV isolates mainly are reported to cause outbreaks in rainbow trout farms in other European countries. This characterisation of VHSV sequences could elucidate and identify future transmission pathways of VHSV within European aquaculture.

\section{MATERIALS AND METHODS}

\section{Nomenclature of Danish genotype Ia VHSV isolates}

Viruses isolated between October 1966 and 1994 were named DK-xxxx, where $\mathrm{x}$ relates to the order of records in the laboratory, e.g. DK-3946. A new record coding system was initiated in 1995 and used until 


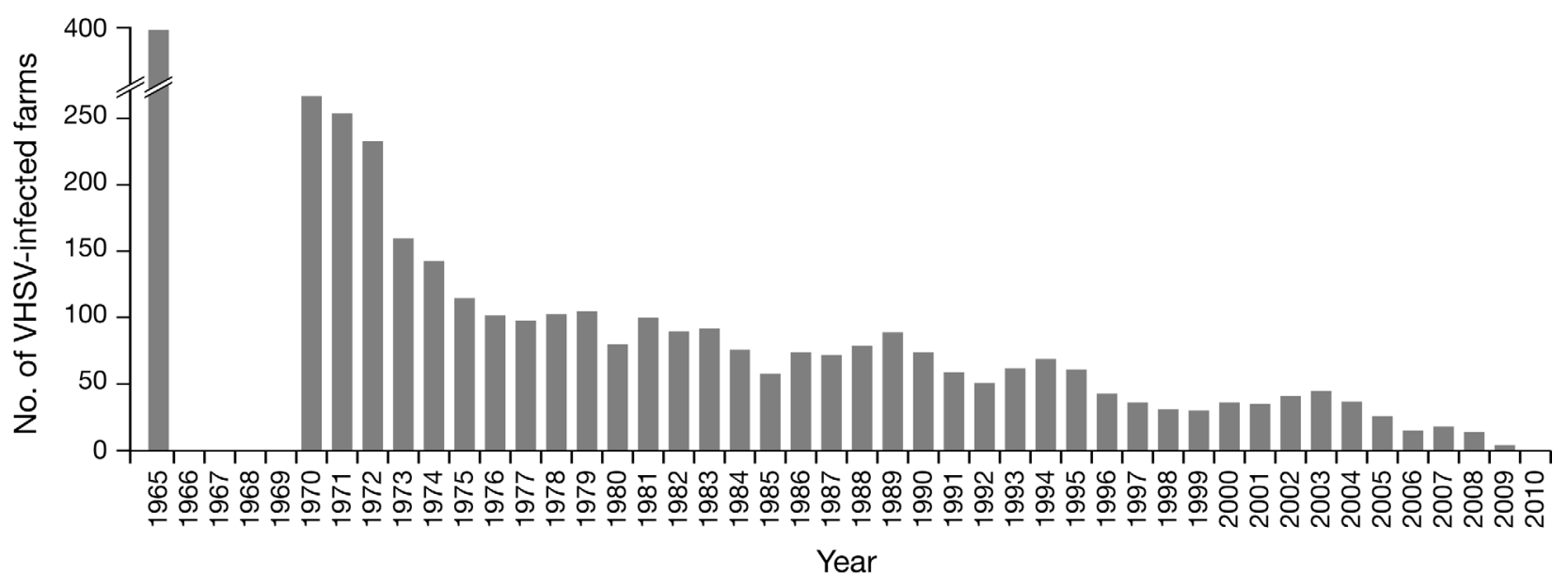

Fig. 1. Number of VHS-infected Danish rainbow trout farms per year since 1965. Sanitation and eradication programs have caused a decrease in the number of infected farms over time. Actual number of infected farms was higher than the number of performed virus isolations, as farms located downstream of an outbreak were automatically assumed to be infected without necessarily being sampled. Since February 2009, no VHS outbreaks have occurred in Denmark and no farms were considered infected in 2010. No statistical data were available for 1966 to 1969

1999. This system provided an indication of the year of isolation: viruses were named using the format DKyy95xxx, where yy is the last 2 numbers in the year of sampling and $\mathrm{x}$ relates to the order of records, e.g. DK-9995361 was obtained in 1999. Virus isolates between 2000 to September 2007 were filed as DK$20 \mathrm{yxxx}$, where $\mathrm{y}$ is the last number in the year and $\mathrm{xxx}$ is the order of analysis, e.g. DK-205090 was isolated in 2005. In October 2007, the record-keeping system was changed again, and virus isolates were named DK-yyyy-50-xxx, where yyyy refers to the year and $\mathrm{xxx}$ to the order of records. If a record includes more samples, a number relating to the specific sample is added at the end of the name, e.g. DK-2009-50-5-1.

\section{Virus isolation}

As Denmark is considered free of infectious haematopoietic necrosis, samples from all farms were analysed for the presence of viruses at least every second year as part of the national routine surveillance program.

From January 2004 to January 2009, when the last Danish VHS outbreak occurred, a total of 57 new Danish VHSV isolates from farmed rainbow trout were obtained from samples covering all outbreaks in Danish rainbow trout farms previously considered to be free of VHS as well as surveillance samples. Outbreak samples from farms were not always collected for laboratory analysis by the competent authorities, e.g. in cases of outbreaks in several farms situated at the same stream in the same time period or when farms were already proven to be VHS infected when inspected. In addition, a further 2 isolates were obtained, one (DK-2008-50-48) was collected from a free-living rainbow trout caught by electrofishing in a stream and the other (2008-50136-2) was collected from wild turbot Psetta maxima caught in the Baltic Sea. The latest Danish VHS outbreak was observed in a rainbow trout farm in January 2009, just before the official national eradication plan was initiated in April 2009. Samples were handled according to procedures described in Commission Decision 2001/183/EC (EU Commission 2001) and VHSV was isolated and propagated using cultures of bluegill fry (BF-2) and/or epithelioma papulosum cyprini (EPC) cell lines. Isolates were passaged 3 times or less before sequencing.

\section{RNA extraction, RT-PCR and sequencing}

Processing of viral isolates for molecular analysis was performed in 2 separate laboratories by 2 distinct methods. In Method 1, viral RNA was prepared from infected cell culture supernatant using RNA affinity spin columns (RNeasy Total RNA kit, Qiagen) according to the manufacturer's instructions. Purified RNA was eluted in $30 \mu \mathrm{l}$ RNase-free water and stored at $-80^{\circ} \mathrm{C}$ until use.

Full-length G-gene PCR products of the isolates were amplified using one of the primer pairs GA, GB, GC or GD as described by Einer-Jensen et al. (2004). 
The optimal primer pair used for amplification of a specific isolate depended on the isolate. The RT-PCR assays were carried out using the OneStep RT-PCR kit from Qiagen according to manufacturer's instructions and an MJ Research DCT-200 (Bio-Rad) thermal cycler. The program profile used had the following components: $50^{\circ} \mathrm{C}$ for $30 \mathrm{~min}, 94^{\circ} \mathrm{C}$ for $15 \mathrm{~min}, 40$ cycles of $94^{\circ} \mathrm{C}$ for $30 \mathrm{~s}, 55^{\circ} \mathrm{C}$ for $30 \mathrm{~s}$ and $72^{\circ} \mathrm{C}$ for $2 \mathrm{~min}$, followed by a final extension $72^{\circ} \mathrm{C}$ for $7 \mathrm{~min}$.

RT-PCR amplified products were sequenced directly without cloning in order to obtain sequences representing the consensus sequence of the virus population. PCR products were purified using PCRClean from Qiagen according to the manufacturer's instructions. Sequencing was performed by a commercial company (DNA Technology, Risskov, Denmark). For bidirectional sequencing, the following 8 primers were used: the 2 amplification primers, seq2+ (5'-CGT GGG GCA ATG GGC-3'), seq2+rev (5'-GCC CAT TGC CCC ACG-3'), seq6+ (5'-CGA TAA GTC ACT CTG TGC-3'), seq6+rev (5'-GCA CAG AGT GAC TTA TCG-3'), seq10+ (5'-TTG CCG GGT CCA GGG-3') and seq10+rev (5'-CCC TGG ACC CGG CAA-3'). Sequences were assembled and quality controlled using the CLC Workbench 5.0 software (www.clcbio.com).

Alternatively, in Method 2, RNA was extracted from $100 \mu \mathrm{l}$ of the virus supernatant using the EZ-1 virus mini kit and the EZ-1 BioRobot (Qiagen), and eluted in a $60 \mu \mathrm{l}$ volume. The reverse transcription, amplification of the G-genes and sequencing was performed as described in Stone et al. (2008).

\section{GenBank accession numbers}

Full-length G-gene sequences were submitted to GenBank and GenBank accession numbers were retrieved as listed in Table 1. Sequences and information on isolates were also inserted into the www.fishpathogen.eu database (Jonstrup et al. 2009). Other already published isolates used in this study are listed in Appendix 1.

\section{Computer analyses}

The phylogenetic tree was made using unique Ggene sequences only. For duplicate sequences, only the sequence of the isolate causing the earliest outbreak was included in the tree. The sequenced Ggenes were all aligned using MUSCLE version 3.8.31 (Edgar 2004) with default parameters. From the
Table 1. Danish VHSV isolates 2004-2009. Watersheds or streams associated with the respective fish farm are as follows. Watershed A relates to the Skjern å watershed and, together with streams B (Hemmet bæk), C (Falen å-Lydum å) and D (Venner å), flows into the Ringkøbing fjord, which opens to the North Sea. Streams E (Hover å) and F (Tim å) flow into Stadil fjord, which flows into Ringkøbing fjord. Stream G (Heager å) flows into the connection between Stadil fjord and Ringkøbing fjord. H pumps brackish/salt water from Ringkøbing fjord. Stream I (Kongeå) flows into the Danish Wadden Sea and stream J (Vejle å watershed) flows into Vejle fjord, which is connected to Kattegat. All isolates were obtained from farmed rainbow trout except DK-2008-50-48, which was obtained from a free-living rainbow trout caught by electrofishing, and 2008-50-136-2, which was obtained from wild turbot caught in the Baltic Sea

\begin{tabular}{|c|c|c|c|c|}
\hline Isolate name & $\begin{array}{c}\text { Date } \\
\text { (mo-yr) }\end{array}$ & $\begin{array}{c}\text { Farm } \\
\text { no. }\end{array}$ & $\begin{array}{l}\text { Watershed } \\
\text { or stream }\end{array}$ & $\begin{array}{c}\text { GenBank } \\
\text { accession no. }\end{array}$ \\
\hline DK-204022 & 01-2004 & 1 & $\mathrm{~A}$ & JF681347 \\
\hline DK-204038 & $02-2004$ & 2 & $\mathrm{~A}$ & JF681342 \\
\hline DK-204040 & $02-2004$ & 2 & A & JF681341 \\
\hline DK-204054 & $02-2004$ & 3 & $\mathrm{E}$ & JF681303 \\
\hline DK-204055 & 03-2004 & 2 & $\mathrm{~A}$ & JF681343 \\
\hline DK-204062 & 03-2004 & 4 & $\mathrm{~A}$ & JF681314 \\
\hline DK-204070 & 03-2004 & 5 & A & JF681334 \\
\hline DK-204072 & 03-2004 & 6 & $\mathrm{~A}$ & JF681320 \\
\hline DK-204114 & 03-2004 & 7 & A & JF681302 \\
\hline DK-204129 & $03-2004$ & 8 & $\mathrm{~A}$ & JF681340 \\
\hline DK-204141 & $04-2004$ & 9 & A & JF681305 \\
\hline DK-204142 & $04-2004$ & 10 & A & JF681307 \\
\hline DK-204157 & $04-2004$ & 11 & $\mathrm{~A}$ & JF681357 \\
\hline DK-204172 & $05-2004$ & 12 & $\mathrm{~A}$ & JF681349 \\
\hline DK-204188 & 05-2004 & 13 & $\mathrm{~A}$ & JF681304 \\
\hline DK-204205 & 06-2004 & 14 & B & JF681319 \\
\hline DK-204249 & $06-2004$ & 15 & $\mathrm{~A}$ & JF681348 \\
\hline DK-204408-2 & $11-2004$ & 16 & A & JF681338 \\
\hline DK-204409 & $11-2004$ & 17 & A & JF681306 \\
\hline DK-205001 & $01-2005$ & 18 & $\mathrm{~A}$ & JF681308 \\
\hline DK-205061 & 03-2005 & 6 & $\mathrm{~A}$ & JF681345 \\
\hline DK-205070 & $03-2005$ & 8 & $\mathrm{~A}$ & JF681328 \\
\hline DK-205090 & $04-2005$ & 19 & A & JF681333 \\
\hline DK-205107 & 04-2005 & 20 & $\mathrm{~F}$ & JF681354 \\
\hline DK-205124-1 & $05-2005$ & 21 & $\mathrm{~A}$ & JF681327 \\
\hline DK-205159 & $05-2005$ & 22 & A & JF681326 \\
\hline DK-205215 & 06-2005 & 23 & A & JF681331 \\
\hline DK-205241 & 07-2005 & 24 & $\mathrm{~A}$ & JF681330 \\
\hline DK-205297-1 & 09-2005 & 25 & $\mathrm{~A}$ & JF681332 \\
\hline DK-205363 & $11-2005$ & 15 & $\mathrm{~A}$ & JF681339 \\
\hline DK-205416 & $12-2005$ & 26 & $\mathrm{~A}$ & JF681346 \\
\hline DK-206126 & $05-2006$ & 27 & $\mathrm{E}$ & JF681310 \\
\hline DK-206130 & $05-2006$ & 28 & $\mathrm{H}$ & JF681329 \\
\hline DK-206136 & $05-2006$ & 29 & $\mathrm{E}$ & JF681309 \\
\hline DK-206137 & $05-2006$ & 30 & $\mathrm{E}$ & JF681312 \\
\hline DK-206195 & $06-2006$ & 31 & $\mathrm{E}$ & JF681311 \\
\hline DK-206252 & $06-2006$ & 32 & $\mathrm{C}$ & JF681313 \\
\hline DK-207017 & 01-2007 & 27 & $\mathrm{E}$ & JF681321 \\
\hline DK-207022 & $02-2007$ & 10 & $\mathrm{~A}$ & JF681315 \\
\hline DK-207023 & $02-2007$ & 14 & $\mathrm{~B}$ & JF681355 \\
\hline DK-207048 & $02-2007$ & 33 & $\mathrm{G}$ & JF681356 \\
\hline DK-207052 & $03-2007$ & 34 & $\mathrm{~A}$ & JF681335 \\
\hline DK-207057 & 03-2007 & 20 & $\mathrm{~F}$ & JF681322 \\
\hline DK-207076-2 & $03-2007$ & 35 & I & JF681344 \\
\hline
\end{tabular}


Table 1 (continued)

\begin{tabular}{|lcccc|}
\hline Isolate name & $\begin{array}{c}\text { Date } \\
(\mathrm{mo-y})\end{array}$ & $\begin{array}{c}\text { Farm } \\
\text { no. }\end{array}$ & $\begin{array}{c}\text { Watershed } \\
\text { or stream }\end{array}$ & $\begin{array}{c}\text { GenBank } \\
\text { accession no. }\end{array}$ \\
\hline DK-207081 & $03-2007$ & 9 & A & JF681316 \\
DK-207085 & $04-2007$ & 36 & D & JF681350 \\
DK-207131 & $04-2007$ & 37 & J & JF681351 \\
DK-207171 & $05-2007$ & 38 & F & JF681317 \\
DK-207193 & $06-2007$ & 38 & F & JF681337 \\
DK-207227 & $06-2007$ & 31 & E & JF681318 \\
DK-2008-50-37-1 & $02-2008$ & 39 & A & JF681359 \\
DK-2008-50-48 & $03-2008$ & - & E & JF681336 \\
2008-50-136-2 & $05-2008$ & - & Baltic Sea & JF681325 \\
DK-2008-50-157-2 & $05-2008$ & 40 & A & JF681353 \\
DK-2008-50-195-2 & $05-2008$ & 41 & I & JF681323 \\
DK-2008-50-223 & $06-2008$ & 25 & A & JF681324 \\
DK-2008-50-251 & $07-2008$ & 42 & A & JF681358 \\
DK-2008-50-308 & $10-2008$ & 28 & H & JF681352 \\
DK-2009-50-5-1 & $01-2009$ & 22 & A & JF681360 \\
\hline
\end{tabular}

alignment, a maximum likelihood (ML) tree was created using PAUP version 4.0b10 (Swofford 2002). The model and parameters used in PAUP were chosen based on the results from JModelTest version 0.1.1 (Posada 2008) which relies on Phyml (Guindon \& Gascuel 2003). The model chosen was GTR+I+G. The parameters set were: Model $=\mathrm{GTR}+\mathrm{I}+\mathrm{G}$; partition $=$ $012345 ;-\operatorname{lnL}=8047.2968 ; \mathrm{K}=250$; freqA $=0.2610$; freqC $=0.2955 ;$ freqG $=0.2326 ;$ freqT $=0.2110 ; \mathrm{R}(\mathrm{a})$ $[\mathrm{AC}]=2.0914 ; \mathrm{R}(\mathrm{b})[\mathrm{AG}]=9.9450 ; \mathrm{R}(\mathrm{c})[\mathrm{AT}]=0.4621$; $\mathrm{R}(\mathrm{d})[\mathrm{CG}]=0.1455 ; \mathrm{R}(\mathrm{e})[\mathrm{CT}]=12.9779 ; \mathrm{R}(\mathrm{f})[\mathrm{GT}]=$ $1.0000 ;$ p-inv $=0.4240 ;$ gamma shape $=1.0060$. Branches with a length less than or equal to $10^{-8}$ substitutions per site were collapsed. The ML tree was created from a starting tree created by neighbor joining (NJ). Using Seqboot version 3.67 (Felsenstein 2005), 100 replicates of the original alignment were created. From the replicated data, $100 \mathrm{ML}$ trees were created using FastTree version 2.1.3 (Price et al. 2010) (model: GTR + Jukes-cantor). Bootstrap values were then found for the nodes in the ML tree created by PAUP by comparing the $100 \mathrm{ML}$ trees with the PAUP tree using CompareToBootstrap.pl (Price 2011). FigTree (Rambaut 2009) was used for visualization of the final tree.

\section{RESULTS}

\section{VHSV isolates collected in Denmark 2004-2009}

In the period 2004-2009, 59 new Danish VHSV isolates were collected from the samples analysed at the Danish National Reference laboratory for
Fish Diseases (Table 1). Of these, 57 were obtained from rainbow trout farms located in a limited area of Jutland (Fig. 2) containing 9 different watersheds, of which 7 were connected through Ringkøbing fjord. Additionally, one farm pumped brackish/salt water from Ringkøbing fjord (2 isolates: DK-206130-1 and DK-2008-50-308). All isolates obtained from rainbow trout are considered to originate from fish reared in freshwater, as the farm pumping salt water usually bought fish from VHS-infected farms. The samples were collected from 42 different rainbow trout farms, of which 33 farms experienced one or more VHS outbreaks. These outbreaks covered 45 isolates, of which DK207171 and DK-207193 were obtained from the same outbreak on different days, and DK-204038, DK-204040 and DK-204055 were likewise isolates obtained from the same outbreak on different days. In addition, one isolate (DK-2008-50-48) was obtained from a free-living rainbow trout caught by electrofishing in a stream and another (200850-136-2) was collected from wild turbot Psetta maxima caught in the Baltic Sea showing no clinical signs.

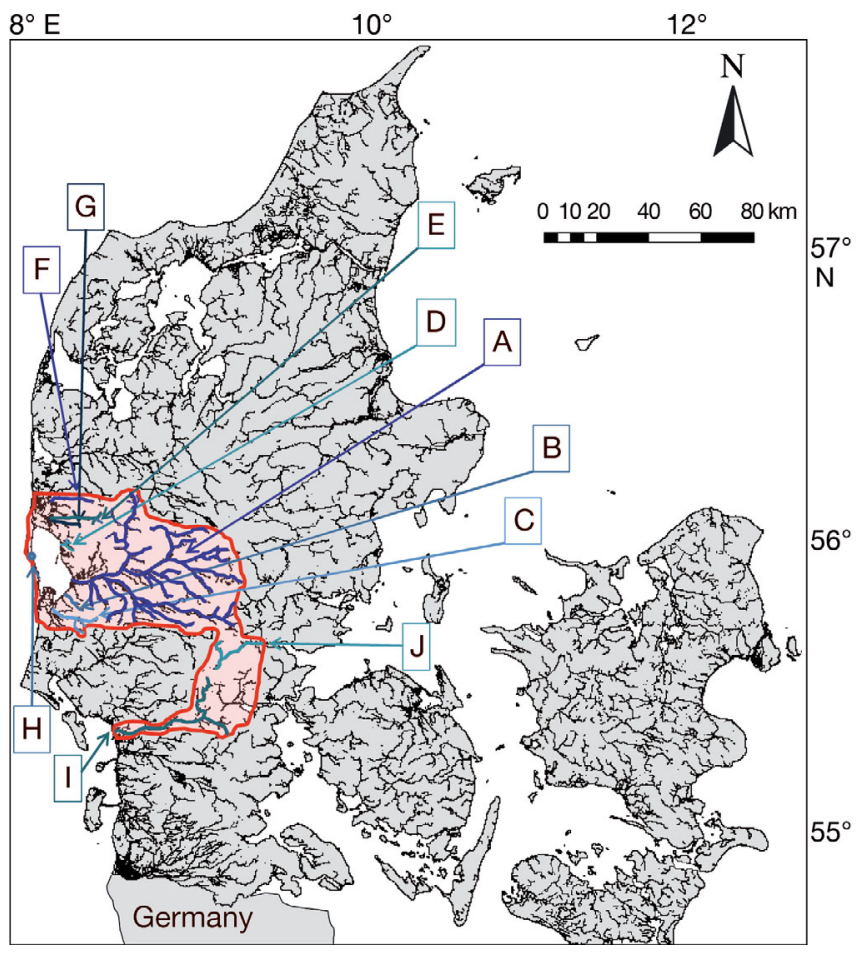

Fig. 2. Watersheds in Denmark considered to be infected with VHS from 2004 to 2009. The area in red contains the streams considered to be endemically infected. The rest of Denmark has been considered to be free of VHS since 1998. VHSV-positive samples are from farms located on watersheds or streams (A-J) described in Table 1 


\section{Sequence analyses}

The full-length G-gene sequences of the 59 Danish VHSV isolates were successfully amplified and sequenced (Table 1). The sequences consisted of 33 unique sequences. Identical sequences were DK$204054=$ DK-204114 = DK-204141 = DK-204142 = DK-204188 = DK-204409 = DK-205001, DK-204072 = DK-204205, DK-204038 = DK-204040 = DK-204055, DK-204172 = DK-204249, DK-204072 = DK205070, DK-205159 = DK-205215 = DK-205241 = DK-205297 1, DK-205070 = DK-205124-1, DK-206126 = DK$206136=$ DK-206137 $=$ DK-206195, DK-206262 = DK207227, DK-207022 = DK-207081, DK-207057 = DK-207171, DK-207085 = DK-207131, DK-207052 = DK2008-50-48, and DK-2008-50-157-1 = DK-200850-223 = DK-2008-50-251 = DK-2009-50-5-1. An ML phylogenetic tree was constructed using the VHSV sequences reported here together with a representative panel of VHSV sequences publicly available from the GenBank database. In total, the analyses covered 118 unique sequences representing all genotypes, including 31 German (2004-2008), one British (2006), one French (1971), one Swiss (1999), one Slovenian (2007), one Austrian (1995) and 19 older Danish (1970-2000) genotype Ia isolates (Fig. 3, Table A1). NJ and Bayesian algorithms produced trees with topologies identical to the ML tree and therefore only the result of the ML tree is presented. The trees confirmed the 4 genotypes and sublineages of genotype I isolates as described previously (Snow et al. 1999, Einer-Jensen et al. 2004). The generated sequence data disclosed that all the 58 Danish VHSV isolates originating from rainbow trout were genotype Ia (Fig. 3A), whereas the single isolate from turbot grouped with the genotype Ib isolates (from the Baltic Sea, Kattegat and Skagerrak).

\section{Genotype Ia isolates divide into two distinct clades: Ia-1 and Ia-2}

The generated phylogenetic tree indicates that genotype Ia isolates segregate into 2 distinct clades

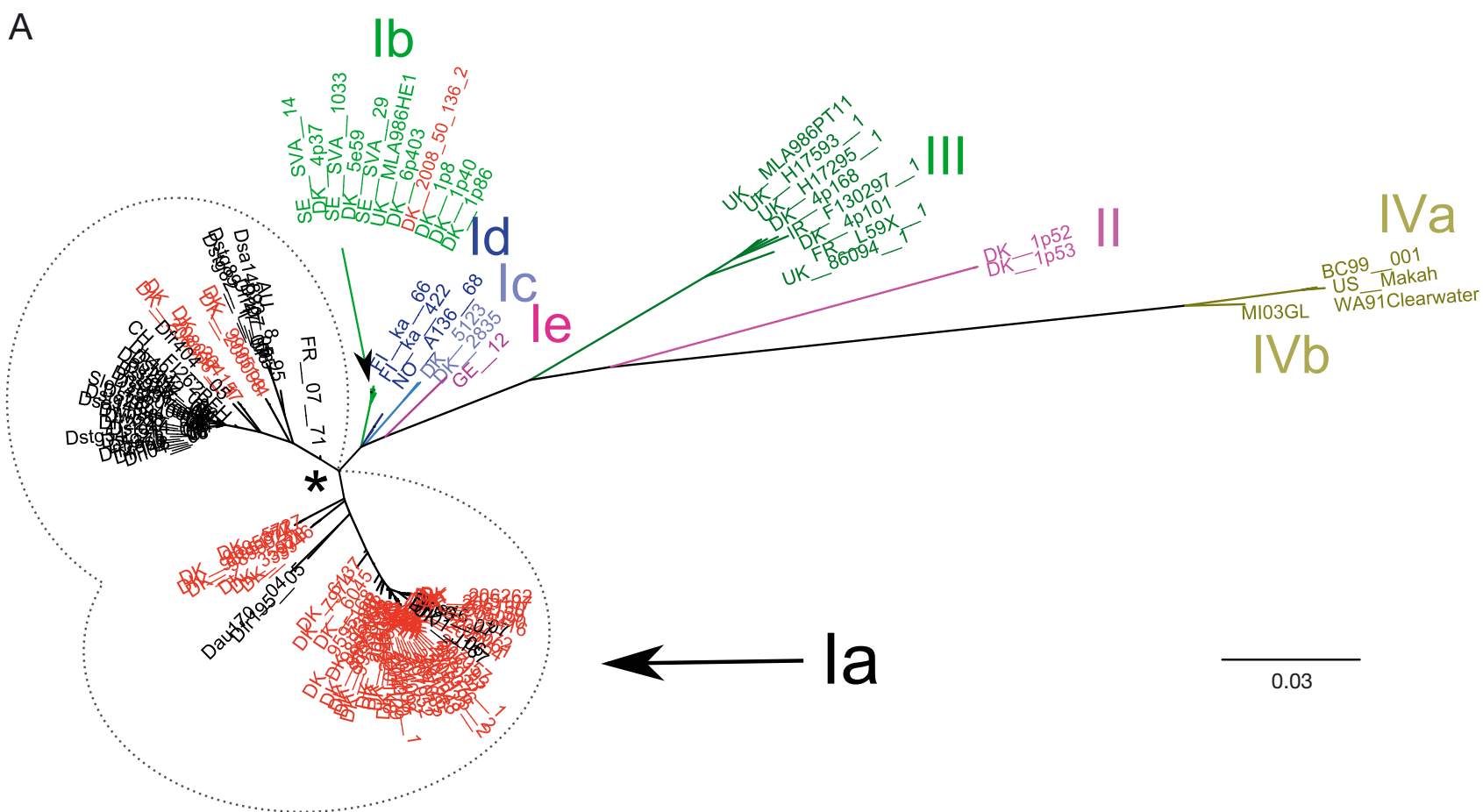

Fig. 3. Phylogenetic relationship of recent Danish VHSV isolates in the context of older Danish isolates and representatives of all known VHSV genotypes, generated from an alignment of 118 unique full length G-gene nucleotide sequences, based on maximum likelihood methodology. Bootstrap reassembling was carried out using 100 replicates of the dataset. Country codes given in Appendix 1. (A) Unrooted tree. Genotype Ia freshwater isolates are encircled by a dashed line. Danish rainbow trout genotype Ia isolates and the marine genotype Ib isolate from turbot are shown in red. Non-Danish genotype Ia isolates are shown in black. Asterisk denotes branch with a bootstrap fraction of 1. (B) Rooted tree showing genotype Ia and clades Ia-1 and Ia-2. The colouring of isolate names is similar to that shown in (A) except that only the Danish genotype Ia isolates are in red. Vertical dotted grey lines indicate subclades of interest. Bootstrap values are written as decimals. Scale bar: number of substitutions per nucleotide site 
that are identified with a bootstrap fraction of 1 (Fig. 3). The clade designated Ia-1 contains 52 unique G-gene VHSV sequences representing 46 isolates that were obtained from Denmark, 5 from Germany and 1 from the UK. In total, the Ia- 1 clade comprises 55 (including duplicate sequences) of the 58 Danish VHSV isolates obtained in 2004-2009 from rainbow trout and 17 of 19 of the older Danish VHSV isolates. The clade designated Ia-2 contains 35 sequences representing 30 isolates from continental European countries outside of Denmark and 5 isolates from Denmark. These data suggest the presence of a geographic signature where the Danish watersheds could have provided an isolated region for the evolution of the clade Ia-1 VHSV isolates (Fig. 2) whereas VHSV isolates from continental European countries outside of Denmark cluster in clade I-a2.

\section{Specific subclades of Danish VHSV isolates have disappeared from the environment}

All isolates within the Ia-1 clade seem to have evolved from one ancestor. However, the Danish isolates within the Ia-1 clade divide into additional subclades (Fig. 3). Isolates causing VHS outbreaks after 2003 group in a specific subclade of isolates. In contrast, the older Danish VHSV isolates (DK-3592B, DK-3946 and DK-3971; and DK-5727, DK-9695377, DK-9895024 and DK-9895174) cluster in 2 other subclades, of which representatives have not been isolated after 1998 (Fig. 3B).

\section{Transmission of VHSV strains from the Danish environment to other European countries}

Six VHSV isolates with unique sequences, obtained from rainbow trout in geographical areas other than Denmark, are present in the Ia-1 clade (marked in black in Fig. 3B). Two German isolates

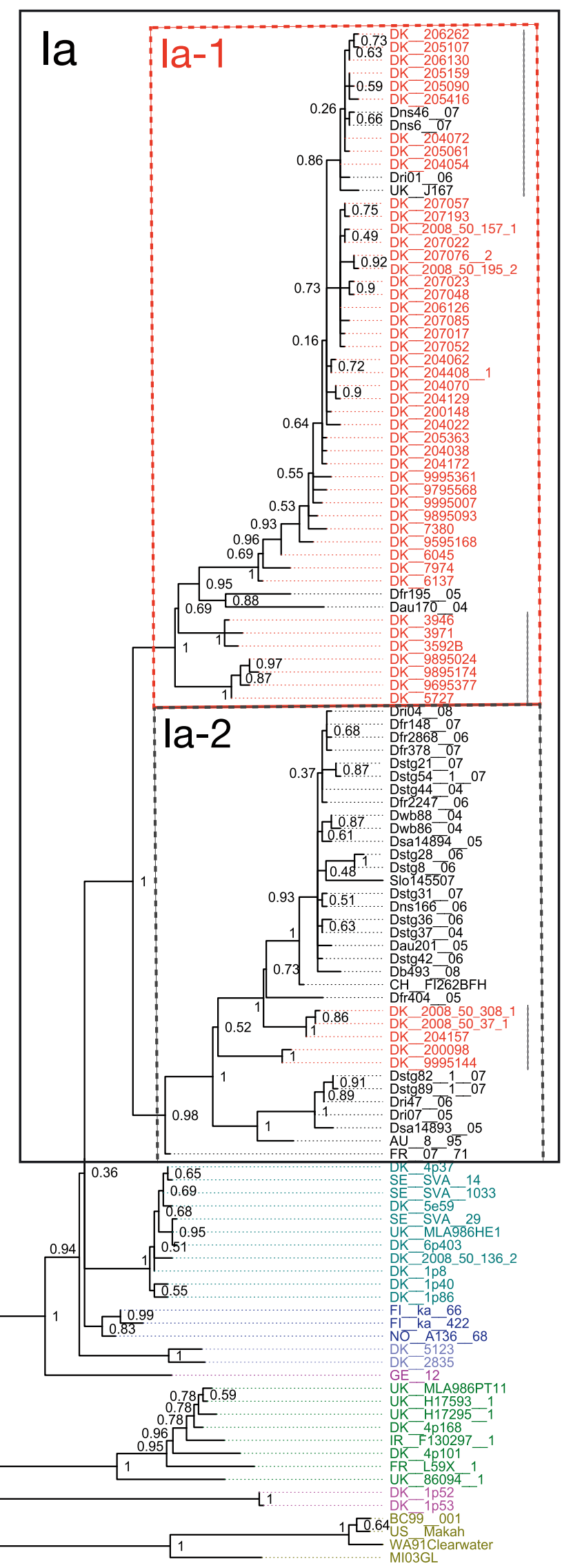

Fig. 3 (continued) 


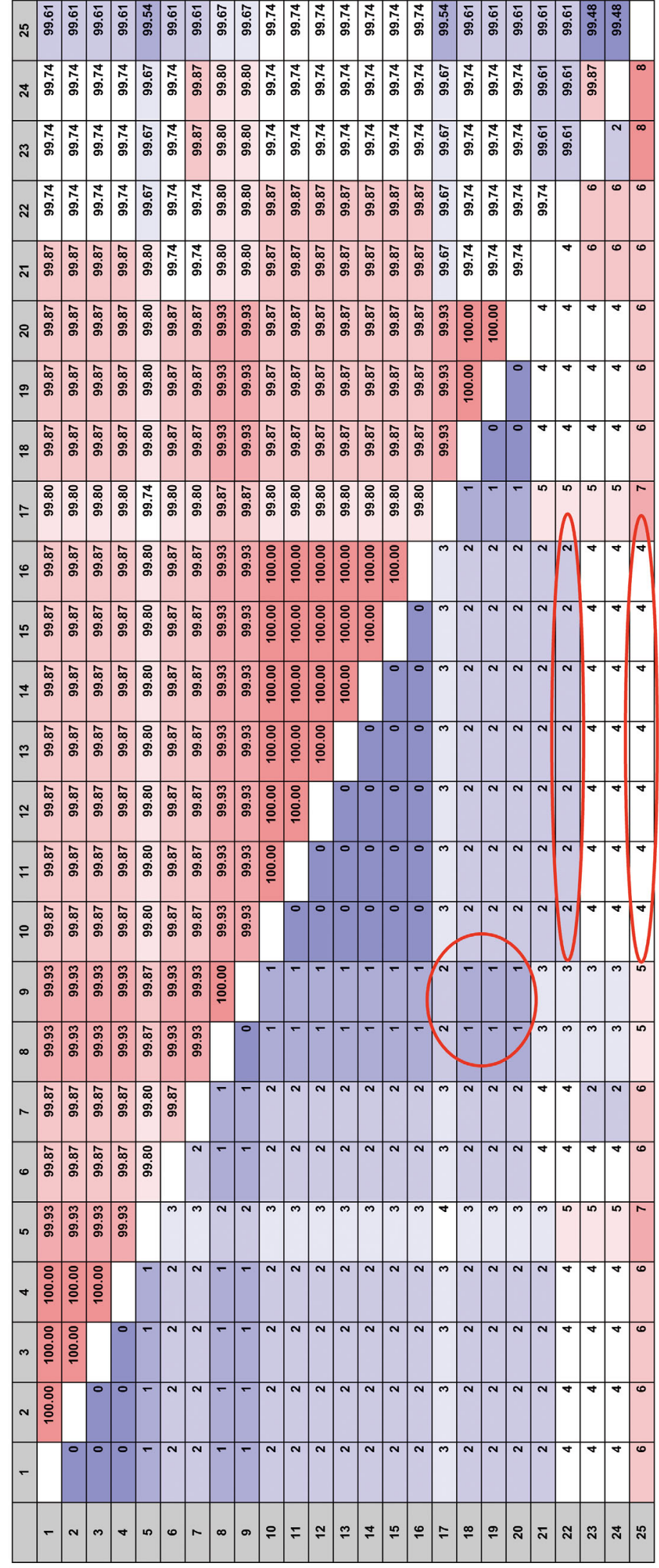

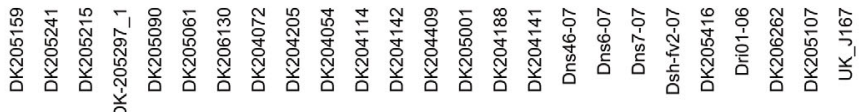

(Dfr195-05 and Dau170-04) are closely related to older Danish isolates. One subclade with a bootstrap fraction of 0.86 contains several recent Danish isolates, and also 4 isolates with unique sequences obtained from outside Denmark (Fig. 3B). Closer examination of the relationship between isolates in this subclade reveals that more isolates with identical Ggene sequences are present (Fig. 4) and that this subclade consists of 19 Danish, 4 German and 1 UK isolate. The UK isolate UK-J167 (Stone et al. 2008) and the German isolate Dri01-06 were both isolated in 2006 and they are both most closely related to Danish VHSV isolates identical to DK-204054 (4 and 2 mutations difference, respectively; Fig. 4). However, 6 other isolates with G-gene sequences identical to DK-204054 were obtained in the period from 2004 to January 2005 (Fig. 4). The 4 German isolates Dns46-07, Dns6-07, Dns707 and Dsh-fv2-07 obtained in 2007 are most closely related to 2 Danish isolates (DK204072 and DK-204205) obtained in 2004 (1 and 2 mutations difference, respectively; Fig. 4). Thus, within subclade Ia-1, each isolate obtained outside of Denmark is most closely related to a VHSV isolate obtained in previous years from within Denmark, but no direct transmission pathway out of Denmark has been identified.

\section{VHSV isolates may survive in an endemically infected environment for up to $4 \mathrm{yr}$}

Genotype Ia isolates that belong to the Ia-2 clade are primarily isolated from rainbow trout in other continental European fish farms (Germany, France, Switzerland, Austria and Slovenia). However, 5 isolates belonging to the Ia-2 clade have infected Danish farms

Fig. 4. Pairwise comparison between full-length VHSV G-gene nucleotide sequences, including the sequences within the subclade identified by a bootstrap fraction of 0.86 in clade Ia-1 containing several recent Danish and German isolates as well as an isolate obtained from the UK. Country codes are given in Appendix 1. The lower comparison displays differences in nucleotides; the upper comparison displays percent identity (blue: low number of differences or percent identity; red: high). Circles indicate the minimum numbers of nucleotide differences between Danish and non-Danish isolates 
(Fig. 3B), indicating that transmission of VHSV to Denmark has occurred. Two related isolates (DK9995144 and DK-200098) were obtained in 1999 and 2000, respectively, from 2 different sites in the Hover å stream (stream $E_{;}$Table 1, Fig. 2). Another subclade consists of the 3 related isolates, DK-204157, DK2008-50-37-1 and DK-2008-50-308-1, that were obtained in April 2004, February 2008 and October 2008, respectively. DK-204157 and DK-2008-50-37-1 caused outbreaks 3 yr and 10 mo apart on 2 different farms located on 2 different tributaries of the Skjern å watershed (stream A; Table 1, Fig. 2), where the isolates may have escaped the routine surveillance program and survived without detection.

\section{DISCUSSION}

Because of an error-prone replication mechanism and the ability to survive mutation, RNA viruses evolve rapidly and have extensive sequence diversity (Holmes 2009). Thus, VHSV provides an ideal opportunity to trace the evolutionary history of viral transmission (Snow 2011). In this study, we sequenced full-length G-genes of all Danish VHSV isolates submitted for diagnostic analysis from 2004 until 2009, when Danish aquaculture experienced its last VHS outbreak. This collection of sequences provides an expansion on diversity with regards to identification of new mutation sites, whereas the diversity measured as percentage identity between nucleotide sequences is not increased significantly. The reported sequences will provide a powerful epidemiological tool for tracing VHSV transmissions.

To date, 4 main genotypes and several sublineages of VHSV have been recognized (Einer-Jensen et al. 2004). Five of these sublineages originate from genotype I. The genotypes and sublineages of VHSV reflect a geographic rather than host-specific distribution. This study confirms previous characterization of genotypes and sublineages (Fig. 3), and all 58 Danish VHSV isolates sampled from rainbow trout were identified as belonging to the group of European genotype Ia freshwater isolates whereas the isolate sampled from turbot caught in the Baltic Sea was classified as belonging to the group of marine genotype Ib isolates that have been identified in, for example, the Baltic Sea.

The phylogenetic analyses performed in this study include 118 unique VHSV G-gene sequences. These analyses identify a segregation of genotype Ia isolates into 2 distinct clades (Fig. 3A), where each clade is coupled to distinct geographical sampling areas.
Within clade Ia-1, approximately $90 \%$ of the VHSV sequences, including duplicates, originated from Danish rainbow trout (Fig. 3) whereas $86 \%$ of isolates of the Ia-2 clade have been collected in continental Europe outside of Denmark. It is therefore likely that the Ia-1 clade of rainbow trout VHSV isolates have evolved within the Danish water catchments containing a high number of infected rainbow trout farms (Fig. 1). The Danish watersheds that are considered to be infected with VHS can be regarded as a geographically isolated area, as they are not shared with any other country (Fig. 2). Furthermore, at least from the period after 1965, the introduction of live rainbow trout into Denmark has been very restrictive and biosecurity measures have been in place in order to reduce the risk of introduction of fish diseases from outside Denmark.

As shown in Figs. $3 \& 4$, there are a few isolates within the Ia-1 clade that have been collected outside Denmark. Assuming that the Ia-1 clade has evolved in the Danish environment, this finding indicates that Danish Ia-1 VHSV isolates have been transferred to other countries, e.g. with exported live fish carrying a sub-clinical infection. The fact that most of these isolates were identified in Germany is supported by the fact that Germany is Denmark's largest export market for live rainbow trout (www.danmarksfiskeriforening.dk).

Some of the Danish isolates are located in clade Ia-2 (Fig. 3). These isolates might have been introduced into Denmark by accidental transmission of an isolate from other continental European countries. Introduction of VHSV from outside the country could have occurred because of failure of biosecurity measures, e.g. by improper disinfection of the many fish transport lorries when returning empty to Denmark. Furthermore, angling is a popular tourist activity in Denmark, with many 'put and take lakes' stocked with farmed fish, and transmission of diseases as a result of using contaminated fishing gear or infected bait may also have occurred.

Molecular epidemiology can be used to infer the most probable origin of a virus. A close genetic relatedness exists between the German isolates present in the Ia-1 clade and some of the Danish isolates. The 2 identical Danish isolates DK-204072 and DK204205 differ from the German isolates Dns6-07, Dns7-07 and Dsh-fv2-07 by 1 nucleotide, and from the German isolate Dns46-07 by 2 nucleotides. Furthermore, the German isolate Dri01-06 differs from the Danish isolate DK-204054 (and the 6 other Danish isolates with identical G-gene sequences) by 2 nucleotides (Fig. 4). These very low differences in 
nucleotides indicate that transmission has occurred from Danish to German farms. Two other isolates of German origin, Dfr195-05 and Dau170-04, cluster with Danish isolates of older origin, from 1998 and before, and because these isolates have not been seen in Denmark more recently, the data suggest that the transmission event is likely to have taken place prior to 1998. The VHS outbreak in the UK in 2006 is considered an isolated event as it is the only outbreak of the disease in freshwater farms in the UK (Stone et al. 2008). The isolate causing the UK outbreak is very likely to have a Danish ancestor as it is located in the Ia-1 clade. The UK isolate displays 4 nucleotides difference to the closest related isolate from Denmark, DK-204054 (and the 6 other Danish isolates with identical G-gene sequences), and 6 nucleotide differences relative to the German Dri01-06 isolate (Fig. 4). As the closest Danish relative to the isolates from UK was obtained at least 1 yr before, a direct transfer from a Danish outbreak is not likely to have occurred. Furthermore, as no direct epidemiological contact information is available, it cannot be concluded whether the VHSV transmitted to the UK had evolved in the endemically infected Danish environment before transmission or whether the transmission from Denmark to the UK occurred through a third party outside of Denmark. Sequencing of a larger number of older Danish VHSV isolates and other continental European isolates might shed further light on the transmission pathways across the Danish border.

Molecular epidemiology can also be used to characterise the coexistence between subpopulations of viruses within the overall population. The occurrence of the VHSV subpopulations in the Danish watersheds seems to be a dynamic process. The Danish isolates within the Ia-1 clade divide into more subclades, all of which seem to have evolved from one common ancestor (Fig. 3B). Outbreaks after 2003 have all been caused from VHSV isolates belonging to one subclade. However, 2 other clades of older Danish VHSV isolates (DK-3592B, DK-3946 and DK3971, obtained between April 1986 and June 1987, and DK-5727, DK-9695377, DK-9895024 and DK9895174, obtained between November 1989 and April 1998) seem to have disappeared from the Danish watersheds. This elimination is not a consequence of physical separation of virus populations into different watersheds, as the isolates from other subclades have been detected more recently in the same watersheds; for example, DK-3592B and DK207227 (identical in sequence to DK-206126) have been isolated from the same fish farm after outbreaks in 1986 and 2007, respectively. The most plausible explanation for the elimination is the eradication program conducted on the involved farms, although this was not necessarily performed immediately after infection or synchronously at neighbouring infected farms. However, it is noted that other factors are known to cause exclusion of a virus strain from an environment with coexisting virus populations (Domingo 2010). At least one of the strains, DK3592B, has been proven to be highly virulent in rainbow trout and is used as positive infection control in all experimental infections performed at the National Veterinary Institute, Technical University of Denmark (Skall et al. 2004). However, whether the disappearance of these subclades is related to successful eradication programs or other causes is unknown.

The isolates DK-204157, DK-2008-50-37-1 and DK-2008-50-308-1 form a subclade within the Ia-2 clade, clearly indicating that they share a recent common ancestor (Fig. 3B). Between the 2 isolates from 2008, DK-2008-50-37-1 and DK-2008-50-308-1, there seems to be a direct transmission pathway as the farm from where the DK-2008-50-308-1 isolate was obtained has regularly been purchasing surviving fish from farms experiencing VHS outbreaks. The link between the isolate from 2004, DK-204157, and DK2008-50-37-1 is more questionable. Introduction, followed by reintroduction of the virus from the same source outside of Denmark may have occurred but, according to fish farmers and competent authorities, this is not likely to have happened. Interestingly, the 2 isolates caused outbreaks at 2 different rainbow trout farms on 2 different tributaries of the same watershed with an interval of $3 \mathrm{yr}$ and 10 mo. This suggests that a VHSV lineage may be capable of surviving undetected in an infected watershed for $3 \mathrm{yr}$ and 10 mo. The ability to survive for such a long period of time is most likely due to the endemically infected status of the watershed, where immediate and synchronous eradication has not necessarily occurred. Currently, EU rules provide 2 ways of demonstrating freedom from VHS in a compartment after an official eradication programme: either through sampling a high number fish over a period of $2 \mathrm{yr}$ or sampling fewer fish over a period of $4 \mathrm{yr}$. These results point to the importance of having longer surveillance periods, e.g. $4 \mathrm{yr}$, before a previously endemically infected area is declared free of VHS. However, when an outbreak occurs as an isolated event, as is the case of the outbreak in the UK or in Norway (Stone et al. 2008, Dale et al. 2009), a surveillance period of 2 yr coupled with greater numbers of samples might be the most appropriate way to obtain disease-free status. 
In conclusion, the present study provides an extended characterisation of European VHSV genotype Ia isolates and contributes to a better understanding of the transmission pathways of VHS. In the future, continued characterisation of VHSV isolates will increase the traceability of isolates and thus our knowledge of transmission mechanisms and how control measures for preventing spread of disease can be implemented more effectively.

Acknowledgements. We thank Maj-Britt Christophersen, Sanne Skovsgaard Madsen, Nicole Nicolajsen, Jette Mølgaard, Marianne Lajer and Mette Eliassen for excellent technical assistance. Torsten Snogdal Boutrup is thanked for discussions on interpretation of data. This study was supported by the EU Network of Excellence EPIZONE, Contract No. FOOD-CT-2006-016236 and by the EU Commission through its financial assistance to the European Union Reference Laboratory for Fish Diseases. Part of this study was also funded under Defra contract C2492 and C3387. The project of final eradication of VHS in Denmark is supported by the Danish Food Industry Agency and the European Fishery Fund.

\section{LITERATURE CITED}

> Dale OB, Ørpetveit I, Lyngstad TM, Kahns S, Skall HF, Olesen NJ, Dannevig BH (2009) Outbreak of viral haemorrhagic septicaemia (VHS) in seawater-farmed rainbow trout in Norway caused by VHS virus Genotype III. Dis Aquat Org 85:93-103

$>$ Domingo E (2010) Mechanisms of viral emergence. Vet Res 41:38

Edgar RC (2004) MUSCLE: multiple sequence alignment with high accuracy and high throughput. Nucleic Acids Res 32:1792-1797

Einer-Jensen K, Ahrens P, Forsberg R, Lorenzen N (2004) Evolution of the fish rhabdovirus viral haemorrhagic septicaemia virus. J Gen Virol 85:1167-1179

Elsayed E, Faisal M, Thomas M, Whelan G, Batts W, Winton $J$ (2006) Isolation of viral haemorrhagic septicaemia virus from muskellunge, Esox masquinongy (Mitchill), in Lake St Clair, Michigan, USA reveals a new sublineage of the North American genotype. J Fish Dis 29:611-619

EU Commission (2001) 2001/183/EC: Commission Decision of 22 February 2001 laying down the sampling plans and diagnostic methods for the detection and confirmation of certain fish diseases and repealing Decision 92/532/EEC (Text with EEA relevance) (notified under document number C(2001) 426). Off J Eur Comm L 67:65-76

EU Commission (2008) 2008/897/EC: Commission Decision of 28 November 2008 approving annual and multiannual programmes and the financial contribution from the Community for the eradication, control and monitoring of certain animal diseases and zoonoses presented by the Member States for 2009 and following years. Off J Eur Union L 322:39-49

EU Council (2006) Council Directive 2006/88/EC of 24 October 2006 on animal health requirements for aquaculture animals and products thereof, and on the prevention and control of certain diseases in aquatic animals. Off J Eur Comm L 328:14-56

Felsenstein J (2005) PHYLIP (Phylogeny Inference Package) version 3.6. Department of Genome Sciences, University of Washington, Seattle, WA

Gadd T, Jakava-Viljanen M, Einer-Jensen K, Ariel E, Koski P, Sihvonen L (2010) Viral haemorrhagic septicaemia virus (VHSV) genotype II isolated from European river lamprey Lampetra fluviatilis in Finland during surveillance from 1999 to 2008. Dis Aquat Org 88:189-198

Gagné N, MacKinnon AM, Boston L, Souter B, Cook-Versloot M, Griffiths S, Olivier G (2007) Isolation of viral haemorrhagic septicaemia virus from mummichog, stickleback, striped bass and brown trout in eastern Canada. J Fish Dis 30:213-223

Guindon S, Gascuel O (2003) A simple, fast, and accurate algorithm to estimate large phylogenies by maximum likelihood. Syst Biol 52:696-704

Hedrick RP, Batts WN, Yun S, Traxler GS, Kaufman J, Winton JR (2003) Host and geographic range extensions of the North American strain of viral hemorrhagic septicemia virus. Dis Aquat Org 55:211-220

> Holmes EC (2009) The evolutionary genetics of emerging viruses. Annu Rev Ecol Evol Syst 40:353-372

> Jonstrup SP, Gray T, Kahns S, Skall HF, Snow M, Olesen NJ (2009) a user-friendly viral haemorrhagic septicaemia virus isolate and sequence database. J Fish Dis 32: 925-929

Kane-Sutton M, Kinter B, Dennis PM, Koonce JF (2010) Viral hemorrhagic septicemia virus infection in yellow perch, Perca flavescens, in Lake Erie. J Gt Lakes Res 36:37-43

Kim SM, Lee JI, Hong MJ, Park HS, Park SI (2003) Genetic relationship of the VHSV (viral hemorrhagic septicemia virus) isolated from cultured olive flounder, Paralichthys olivaceus in Korea. J Fish Pathol 16:1-12

Lee WL, Yun HM, Kim SR, Jung SJ, Oh MJ (2007) Detection of viral hemorrhagic septicemia virus (VHSV) from marine fish in the South Western Coastal Area and East China Sea. J Fish Pathol 20:201-209

> López-Vázquez C, Raynard RS, Bain N, Snow M, Bandín I, Dopazo CP (2006) Genotyping of marine viral haemorrhagic septicaemia virus isolated from the Flemish Cap by nucleotide sequence analysis and restriction fragment length polymorphism patterns. Dis Aquat Org 73:23-31

Meier W, Schmitt M, Wahli T (1994) Viral hemorrhagic septicemia (VHS) of nonsalmonids. Annu Rev Fish Dis 4: 359-373

Meyers TR, Winton JR (1995) Viral hemorrhagic septicemia virus in North America. Annu Rev Fish Dis 5:3-24

Nishizawa $T$, Iida $H$, Takano R, Isshiki $T$, Nakajima $K$, Muroga K (2002) Genetic relatedness among Japanese, American and European isolates of viral haemorrhagic septicemia virus (VHSV) based on partial G and P genes. Dis Aquat Org 48:143-148

Nishizawa T, Savas H, Isidan $H$, Üstündag C, Iwamoto $H$, Yoshimizu M (2006) Genotyping and pathogenicity of viral hemorrhagic septicemia virus from free-living turbot (Psetta maxima) in a Turkish coastal area of the Black Sea. Appl Environ Microbiol 72:2373-2378

OIE (2009) Viral haemorrhagic septicaemia. In: Manual of diagnostic tests for aquatic animals. World Organisation for Animal Health, Paris. Available at www.oie.int/ fileadmin/Home/eng/Health_standards/aahm/2010/2.3.09. VHS.pdf 
Olesen NJ (1998) Sanitation of viral haemorrhagic septicaemia (VHS). J Appl Ichthyol 14:173-177

Olesen NJ, Korsholm H (1997) Control measures for viral diseases in aquaculture: eradication of VHS and IHN. Bull Eur Assoc Fish Pathol 17:229-233

Posada D (2008) jModelTest: phylogenetic model averaging. Mol Biol Evol 25:1253-1256

Price MN (2011) Fast Tree-Comparison Tools. Available at www.microbesonline.org/fasttree/treecmp.html

> Price MN, Dehal PS, Arkin AP (2010) FastTree 2 - approximately maximum-likelihood trees for large alignments. PLoS One 5:e9490

Raja-Halli M, Vehmas TK, Rimaila-Pärnänen E, Sainmaa S, Skall HF, Olesen NJ, Tapiovaara H (2006) Viral haemorrhagic septicaemia (VHS) outbreaks in Finnish rainbow trout farms. Dis Aquat Org 72:201-211

Rambaut A (2009) FigTree v1.3.1. Available at http://tree. bio.ed.ac.uk/software/figtree/

Rasmussen CJ (1965) A biological study of the Egtved disease (INUL). Ann NY Acad Sci 126:427-460

Schäperclaus W (1954) Undersøgelse af sygdom hos ørrederne i danske ørreddambrug og forslag til bekæmpelse heraf. Ferskvandsfiskeribladet 52:145-149, 161-166

Schlotfeldt HJ, Ahne W, Jørgensen PEV, Glende W (1991) Occurrence of viral haemorrhagic septicaemia in turbot (Scophthalmus maximus) - a natural outbreak. Bull Eur Assoc Fish Pathol 11:105-107

Schütze H, Mundt E, Mettenleiter TC (1999) Complete genomic sequence of viral hemorrhagic septicemia virus, a fish rhabdovirus. Virus Genes 19:59-65

Skall HF, Slierendrecht WJ, King JA, Olesen NJ (2004) Experimental infection of rainbow trout Oncorhynchus mykiss with viral haemorrhagic septicaemia virus isolates from European marine and farmed fishes. Dis Aquat Org 58:99-110
Skall HF, Olesen NJ, Mellergaard S (2005) Viral haemorrhagic septicaemia virus in marine fish and its implications for fish farming - a review. J Fish Dis 28: 509-529

> Snow M (2011) The contribution of molecular epidemiology to the understanding and control of viral diseases of salmonid aquaculture. Vet Res 42:56

Snow M, Cunningham CO, Melvin WT, Kurath G (1999) Analysis of the nucleoprotein gene identifies distinct lineages of viral haemorrhagic septicaemia virus within the European marine environment. Virus Res 63:35-44

> Snow M, Bain N, Black J, Taupin V and others (2004) Genetic population structure of marine viral haemorrhagic septicaemia virus (VHSV). Dis Aquat Org 61: $11-21$

Stone DM, Ferguson HW, Tyson PA, Savage J and others (2008) The first report of viral haemorrhagic septicaemia in farmed rainbow trout, Oncorhynchus mykiss (Walbaum), in the United Kingdom. J Fish Dis 31:775-784

Swofford DL (2002) PAUP* : phylogenetic analysis using parsimony (and other methods) 4.0 beta. Sinauer Associates, Sunderland, MA

Thompson TM, Batts WN, Faisal M, Bowser P and others (2011) Emergence of viral hemorrhagic septicemia virus in the North American Great Lakes region is associated with low viral genetic diversity. Dis Aquat Org 96:29-43

> Toplak I, Hostnik P, Rihtarič D, Olesen NJ, Skall HF, Jenčič V (2010) First isolation and genotyping of viruses from recent outbreaks of viral haemorrhagic septicaemia (VHS) in Slovenia. Dis Aquat Org 92:21-29

Walker PJ, Benmansour A, Dietzgen R, Fang RX and others (2000) Family Rhabdoviridae. In: Van Regenmortel MHV, Fauquet CM, Bishop DHL, Carstens EB and others (eds) Virus taxonomy. Classification and nomenclature of viruses. Academic Press, San Diego, CA, p 563-583 
Appendix 1. Previously published isolates used for comparative purposes in the present study. Country codes of the sampling laboratory are displayed as the initial part of the name, except for German and North American (genotype IV) isolates. Danish: DK $;$ German: D; French: Fr; Slovenian: Slo; Austrian: AU; Swiss: CH; Norwegian: NO; Swedish: SE, Finnish: Fi; Irish: IR; British: UK; Georgian: GE

\begin{tabular}{|c|c|c|c|c|c|}
\hline Isolate & GenBank no. & Isolate & GenBank no. & Isolate & GenBank no. \\
\hline Genotype Ia & & Dri01-06 & EU708772 & \multicolumn{2}{|c|}{ Genotype Ib-Ie, II, II and IV } \\
\hline Danish & & Dri47-06 & EU708776 & & \\
\hline DK-3592B & X66134 & Dns166-06 & EU708770 & $\begin{array}{l}\mathrm{NO}-\mathrm{A} 163-68 \\
\mathrm{DK}-2835\end{array}$ & AY546621 \\
\hline DK-3946 & AY546586 & Dstg8-06 & EU708803 & $\begin{array}{l}\text { DK-2835 } \\
\text { DK-5123 }\end{array}$ & AY546585 \\
\hline DK-3971 & AY546587 & Dstg28-06 & EU708805 & DK-5123 & AY546588 \\
\hline DK-5727 & AY546589 & Dstg36-06 & EU708807 & 1p8 & AY546573 \\
\hline DK-6045 & AY546592 & Dstg42-06 & EU708808 & $1 \mathrm{p} 40$ & AY546575 \\
\hline DK-6137 & AY546593 & Dfr2247-06 & EU708764 & 1p52 & AY546576 \\
\hline DK-7380 & AY546594 & Dfr2868-06 & EU708765 & 1p53 & AY546577 \\
\hline DK-7974 & AY546595 & Dns6-07 & EU708767 & $1 \mathrm{p} 86$ & AY546579 \\
\hline DK-9595168 & AY546596 & Dns46-07 & EU708769 & $4 p 37$ & FJ460590 \\
\hline DK-9695377 & AY546597 & Dstg21-07 & EU708804 & 4p101 & AY546581 \\
\hline DK-9795568 & AY546598 & Dstg31-07 & EU708806 & $5 e 59$ & AY546583 \\
\hline DK-9895024 & AY546599 & Dstg54-1-07 & EU708809 & $6 \mathrm{p} 403$ & AY546584 \\
\hline DK-9895093 & AY546600 & Dstg82-1-07 & EU708810 & SVA-14 & AY546622 \\
\hline DK-9895174 & AY546603 & Dstg89-1-07 & EU708811 & SVA-29 & AY546624 \\
\hline DK-9995007 & $\begin{array}{l}\text { AY } 440000 \\
\text { AY546601 }\end{array}$ & Dfr148-07 & EU708762 & SVA-1033 & FJ460591 \\
\hline DK-9995144 & AY546602 & Dfr378-07 & EU708763 & Fi-ka-66 & am086354 \\
\hline DK-9995361 & AY546604 & Dri04-08 & EU708775 & Fi-ka-422 & am086356 \\
\hline DK-200098 & AY546605 & Db493-08 & EU708757 & GE-12 & AY546619 \\
\hline German & & French & & UK-86094-1 & AY546628 \\
\hline Dwb86-04 & EU708814 & FR-07-71 & AJ233396 & IR-F130297-1 & AY546620 \\
\hline & EUT70814 & & & H17593-1 & AY546630 \\
\hline Dwb88-04 & EU708815 & Austrian & & H17295-1 & AY546629 \\
\hline Dstg44-04 & EU708798 & AU-8/95 & AY546570 & MLA986PT11 & AY546632 \\
\hline Dau170-04 & EU708742 & British & & MLA986HE1 & AY546631 \\
\hline Dau201-05 & EU708743 & UK-J167 & JN180851 & FR-L59X & AY546618 \\
\hline Dri07-05 & EU708773 & & & WA91Clearwater & DQ401189 \\
\hline Dfr195-05 & EU708760 & Swiss & & ВC99-001 & DQ401195 \\
\hline Dfr404-05 & EU708761 & CH-FI262BFH & AY546571 & MI03GL & DQ401193 \\
\hline Dsa14893-05 & EU708787 & Slovenian & & US-Makah & $\mathrm{U} 28747.1$ \\
\hline Dsa14894-05 & EU708788 & Slo1455/07 & GQ292534 & & \\
\hline
\end{tabular}

Editorial responsibility: Mark Crane, Geelong, Victoria, Australia
Submitted: September 25, 2011; Accepted: January 13, 2012 Proofs received from author(s): April 16, 2012 